\title{
PERKEMBANGAN WACANA IDENTITAS ARSITEKTUR DALAM JURNAL-JURNAL ARSITEKTUR DI AWAL ABAD XX DI HINDIA BELANDA
}

\author{
Mahatmanto \\ Program Studi Arsitektur Fakultas Arsitektur dan Desain Universitas Kristen Duta Wacana \\ Gedung Agape lantai 5, Jl. Dr. Wahidin 5-25 Yogyakarta \\ *Email: mahatmanto@staff.ukdw.ac.id
}

\begin{abstract}
The transition of the 19th century to the 20th century known as the flowering period of the printed mass media in the West and the colonies. Similarly, in the Dutch East Indies, in the turn of the century, many publications are created, written and read by the architects who come to enjoy this print technology development in order to always be able to follow the progress in the Netherlands. At the turn of the century it was known four publications that circulated among architects in the Indies. Ideologies and interests with each of them carrying, mixing, and developed the ideas of architecture are increasingly different from the original. This process is in line with the development of the ideas of nationalism in a society that demands the assertion of identity in the form of nation-state nation Indonesia. This study surveyed the development of the contents of the four publications related to architecture in the Dutch East Indies, which is the method of Discourse Analysis, found patterns of discourse that lies behind the development of architectural identity discourse in the aftermath of Indonesia's independence.
\end{abstract}

Keywords: Modernization, Colonialization, Media, Discourse, Identity.

\section{PENDAHULUAN}

Wacana identitas arsitektur muncul tenggelam dalam sejarah, namun tidak habishabisnya dibicarakan, dengan aktor yang baru dan alasan-alasan yang baru pula untuk memunculkannya. Karena sebuah wacana adalah produk publik maka pemunculan dan perkembangannya harus dicari di ruang publik.

Ruang publik yang secara dramatik mengubah tatanan masyarakat adalah munculnya teknologi komunikasi modern yang berupa publikasi tercetak: buku, berkala, dan koran.

Di peralihan abad ke Abad XX di Hindia Belanda -sebagaimana yang berlangsung di Barat- terjadi fenomen peningkatan drastis publikasi tercetak. Mengikuti Patrick Collier et al.(2008) peningkatan itu tidak hanya pada jumlah, namun juga pada jenis serta isi seiring dengan berkembangnya cabang-cabang ilmu pengetahuan baru dan kesadaran identitas bangsa.

Pemerintah Hindia Belanda pun mengeluarkan Undang-undang Pers pada tahun 1854 yang membolehkan pribumi menerbitkan koran.

Didukung oleh perkembangan teknologi percetakan, fotografi serta dibukanya Terusan Suez (1869) yang memendekkan jarak Eropa dengan tanah jajahan di Hindia Belanda, mengukuhkan kolonialisasi dan melancarkan globalisasi nilai-nilai modern dari Barat.

Diberlakukannya Politik Etis di Hindia Belanda pada tahun 1903 yang mempersiapkan tenaga-tenaga terdidik dari kalangan pribumi untuk menjalankan birokrasi kolonial, telah melahirkan sekelompok elit pribumi yang mampu membaca dan menulis dalam publikasi tercetak. Termasuk di sini adalah para teknisi bangunan (bouwkundigen) dan arsitek, yang setelah mengenal pengetahuan membangun baru dari bacaannya juga ikut menyebarkan 
pengetahuan itu lewat tulisan dan terjemahan yang dipublikasikan.

Masuknya gagasan-gagasan baru, bahan bangunan, maupun teknik konstruksi yang diterbitkan lewat bacaan telah mendorong terjadinya pertukaran gagasan secara publik.

Studi mengenai dampak penerbitan berkala tercetak dalam masyarakat modern pernah dilakukan oleh Scholes and Wulfman (2010). Demikian pula studi mengenai peran pers dalam membina identitas kebangsaan, sudah diawali oleh Ben Anderson (2006) maupun Ahmat Adam (2003). Studi-studi tersebut memperlihatkan bahwa ada peran penting yang diakibatkan oleh kemajuan teknologi percetakan dalam membentuk dan mendistribusikan gagasan modernitas serta kesadaran identitas bangsa.

Studi-studi khusus mengenai peran publikasi dan media dalam arsitektur diawali oleh Colomina (1994) tentang arsip-arsip arsitek Le Corbusier dan Adolf Loos, dan Rattenbury (2002) yang mengkaji pembentukan citra arsitektur oleh media. Studi-studi ini membuka perspektif penelitian sejarah arsitektur untuk melacak bagaimana gagasan Arsitektur Modern mulai terbentuk dan tersebar di seluruh muka bumi melalui media komunikasi tercetak.

Identitas arsitektural mulai dipikirkan dan diusahakan kehadirannya, terjadi karena dikenalnya pengetahuan baru dalam membangun yang datang secara masif dalam rupa tulisan, foto, gambar hingga bangunan yang bermunculan dalam masyarakat urban di kota-kota besar Hindia-Belanda. Kesadaran akan identitas arsitektural itu berlangsung melalui proses yang terbina secara publik melalui media cetak.

Penelitian ini adalah bagian dari penelitian yang sudah dan sedang dikerjakan untuk memetakan perkembangan wacana arsitektur Indonesia dalam media (Mahatmanto, 2004; Mahatmanto, 2014; Mahatmanto, 2015). Pada kesempatan ini secara khusus hendak dikenali dinamika muncul dan berkembangnya wacana identitas arsitektur sebagaimana dicatat oleh berkala.

Semua sumber dokumen untuk studi ini menggunakan arsip koleksi berkala yang tersedia di Perpustakaan Nasional di Jakarta, dan Perpustakaan Museum Sonobudoyo Yogyakarta.

\section{METODA PENELITIAN}

Studi sejarah mengandalkan arsip dan dokumen tertulis. Perkembangan gagasan seperti halnya wacan modernitas dan wacana identitas arsitektur ini hendak dirunut di dalam dokumen-dokumen tertulis yang diterbitkan.

Berkala (periodicals, tijdschriften) sebagai publikasi tercetak yang terbit secara teratur merupakan dokumen dan lokasi terbaik untuk mengikuti perkembangan gagasan mengenai modernitas dan identitas. Kelebihan berkala dari pada dokumen resmi adalah, dalam berkala di dalamnya berlangsung interaksi dua arah, antara penulis dan pembaca sehingga studi mengenai berkala ini dapat memperlihatkan wacana yang sedang berkembang di masanya.

Studi ini menelusuri perkembangan tajuk beberapa berkala di peralihan abad XIX-XX yang dilacak melalui Daftar Isi sejak terbit hingga tutupnya. Pengelompokan isi ke dalam tajuk-tajuk itu mengandalkan pengelompokkan yang dibuat oleh berkala itu sendiri yang mencerminkan ideologi pandangan dan kepentingan mereka masing-masing. Pada akhirnya hendak dibuat refleksi mengenai kecenderugan, kontinuitas dan diskontinuitas wacana identitas arsitektur di peralihan abad XIX-XX.

\section{HASIL DAN PEMBAHASAN}

Dalam Encyclopaedie van NederlandschIndie, 1921 [10] di peralihan abad XIX-XX hingga menjelang pendudukan Jepang 1942, dikenal 4 buah berkala (Tabel 1) yang terbit secara teratur di Hindia-Belanda, yang isinya berkaitan dengan Arsitektur, kebudayaan, sejarah, kesenian dan kerajinan masyarakat pribumi.

Tabel 1. Berkala mengenai teknik bangunan yang terbit di Hindia-Belanda di peralihan abad XIX-XX

\begin{tabular}{llc} 
& \multicolumn{3}{c}{ Tijdschrift van het } \\
KIVI & $\begin{array}{l}\text { Koninklijk Instituut van } \\
\text { Ingenieurs. Afdeeling } \\
\text { Nederlandsch-Indie }\end{array}$ & $1875-1914$ \\
$\mathbf{I B T}$ & $\begin{array}{l}\text { Indisch Bouwkundig } \\
\text { Tijdschrift }\end{array}$ & $1898-1933$ \\
NION & $\begin{array}{l}\text { Nederlandsch-Indie Oud } \\
\text { en Nieuw }\end{array}$ & $1916-1935$ \\
$\mathbf{L T}$ & Locale Techniek & $1932-1940$ \\
\hline
\end{tabular}


Berkala dari perhimpunan para insinyur Institut Kerajaan Belanda (KIVI) bagian Hindia Belanda ini diterbitkan di kota Batavia. Hampir di semua edisinya, pengelompokan isi terdiri atas: laporan notulen rapat anggota, laporan perjalanan, dan artikel keteknikan untuk meningkatkan pengetahun anggotanya (Gambar $1)$.

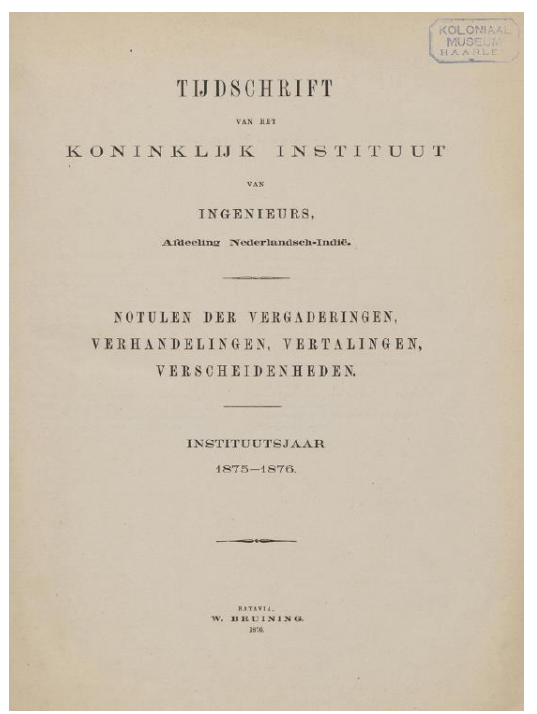

Gambar 1. Edisi Perdana KIVI, 1876

Terbit paling awal tahun 1875, dan edisi terakhir ditemukan 1914 tanpa keterangan mengapa berkala ini terhenti. Dari awal hingga akhir, berkala ini tidak memuat hal yang berkaitan dengan masalah-masalah arsitektural lokal. Edisi perdana Pada edisi terakhir hanya memuat 3 artikel: tentang sistem pondasi yang cocok untuk tanah tropik, pengeboran sumur artesis di Batavia, dan perkembangan percobaan lokomotif yang baru (Gambar 2).

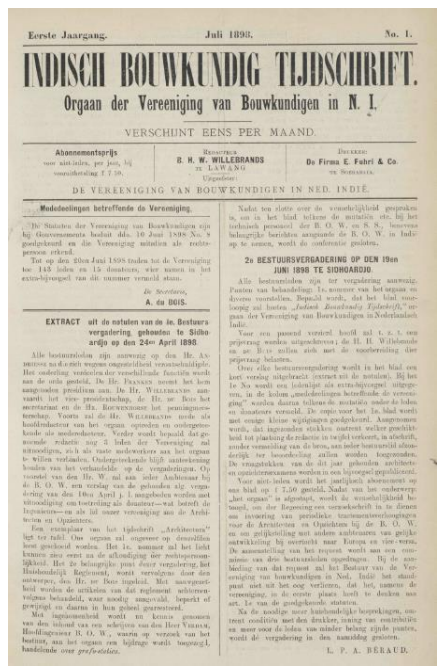

Gambar 2. Edisi Perdana IBT, 1898
Adapun isi IBT, dari semula telah dikelompokkan menurut tajuk. Tajuk ini mengalami beberapa kali perbahan nama dan komposisinya.

Diterbitkan sebagai berkala resmi dari perhimpunan teknisi bangunan Vereeniging van Bouwkundigen in Nederlandsch-Indie (VvBNI), berkala ini merupakan berkala paling lama hidup dengan rentang waktu 1899-1931.

Semula terbit dua bulanan namun frekuensi kemudian berubah jadi bulanan atau malah lebIh jarang menyesuaikan keadaan organisasi. Pengelompokan tajuk juga mengalami dinamika kadang hanya terdiri dari Berita Keanggotaan dan laporan keuangan, namun kadang lebih kaya dan beragam dengan artikel-artikel tentang statika dan irigasi, laporan perjalanan, berita dan ulasan proyek yang sedang dilakukan, ulasan mengenai proyek yang sedang dibicarakan oleh pers di luar negri, review buku, pengumuman sayembara dan hasilnya, maupun soal-soal untuk ujian calon arsitek dari perhimpunan VvBNI itu.

Disebutkan dalam notulensi rapat perdana perhimpunan VvBNI di Sidoardjo, tujuan berkala ini diterbitkan selain sebagai pengikat antar anggota yang tersebar di Nusantara, juga diniatkan menjadi cara untuk meningkatkan pengetahuan dan ketrampilan anggotanya yang dikeluhkan amat ketinggalan.

Diterbitkan dan dicetak dari tempat yang berbeda-beda sepanjang sejarahnya, mengikuti kedudukan pemimpin VvBNI yang digilir. Mula-mula di Surabaya dan sekitarnya (Lawang, Malang), kemudian Bandung, Batavia dan akhirnya di Semarang.

Anggota VvBNI, meski pun disebut sebagai ahli teknik bangunan dan arsitek, kesibukan mereka lebih pada pembangunan infrastruktur, khususnya irigasi, jembatan dan jalan raya serta pelabuhan-pelabuhan. Sejak awal, IBT sudah menerbitkan foto-foto proyek irigasi dan menyajikan peta-peta berwarna dimana proyek-proyek itu dilangsungkan. Artinya, IBT tergolong maju dalam mengikuti teknologi percetakan.

Keanggotaan VvBNI sejak awal berdirinya tidak hanya berisi arsitek Belanda yang bekerja di Hindia Belanda, namun sudah terdapat 4 nama asli pribumi yang salah satu darinya-Aboekasan Atmodirono- kelak akan dicatat sebagai Arsitek Pribumi pertama Indonesia. 
Karena kelangsungannya tergantung pada iuran anggota VvBNI maka fluktuasi penerbitan pun sering terganggu. Ketika para arsitek dan ahli teknik bangunan tidak lagi menjadi tanggungjawab pemerintah pusat dan diserahkan ke pemerintah daerah, sebagai konsekuensi dari Undang-undang Desentralisasi, maka keberadaan VvBNI melemah dan diluidasi pada tahun 1927. Berkala IBT tetap terbit dengan bergabung dengan berkala Locale Techniek sehingga isinya pun mengalami berubah.

Berkala NION yang terbit di Batavia tidak mewakili suatu profesi keteknikan bangunan seperti KIVI dan IBT tapi merupakan majalah umum yang dipersembahkan untuk pembaca yang meminati seni bangunan (istilah waktu itu untuk Arsitektur), arkeologi, etnografi, kerajinan, ekonomi dan perdagangan ("gewijd aan bouwkunst, archeologie, land-en volkenkunde, kunstnijverheid, handel en verkeer") (Gambar 3).

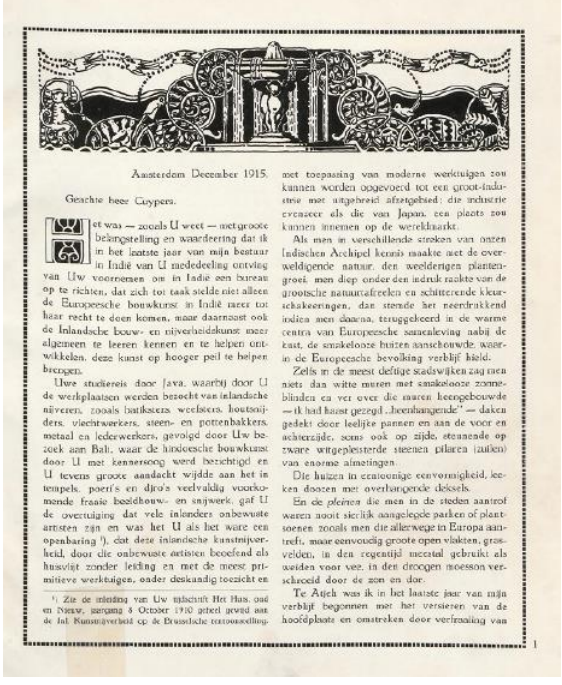

Gambar 3. Terbitan Perdana NION, 1916

Sesuai dengan nama majalahnya, banyak studi mengenai kebudayaan pribumi dilaporkan dalam perbandingannya dengan yang datang dari Eropa. Dalam edisi perdananya terdapat artikel dari arsitek Henri Maclaine Pont tentang rancangan kantor pusat Jawatan Kereta Api swasta SCS di Tegal yang diterangkan di situ sebagai upaya modernisasi arsitektur tropis dan ketrampilan tukang pribumi (Pont, 1916).

Ini adalah berkala yang pertama menampilkan halaman-halaman foto berwarna satu halaman penuh, misalnya untuk artikel mengenai kain-kain ikat dan batik di Nusantara (Gambar 4).

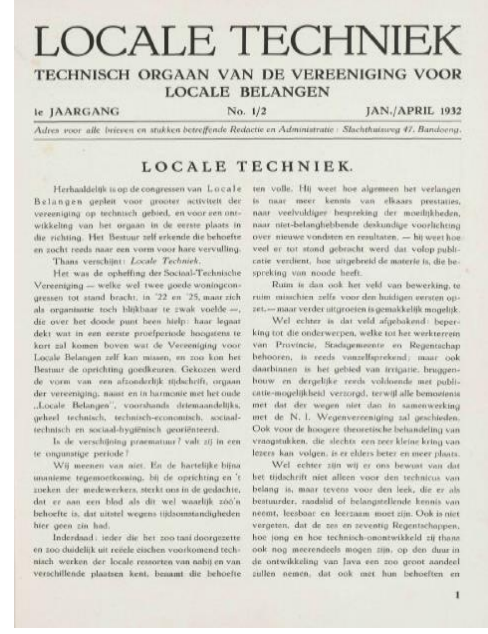

Gambar 4. Terbitan Perdana Locale Techniek, 1932

Berkala Locale Techniek yang terbit pada tahun 1932 merupakan media resmi khusus untuk hal-hal teknis dari Forum Locale Belangen yakni forum komunikasi antar Dewan Kota se Hindia Belanda, sebagai realisasi saran Kongres Desentralisasi di Bandung 1911. Berkala ini kemudian digabung dengan IBT ketika IBT dilikuidasi pada tahun 1927, dan keduanya meneruskan terbit bersama dengan nama IBT-Locale Techniek pada tahun 1934.

Sesuai namanya, Locale Belangen [urusan-urusan lokal) merupakan forum yang dalam tiap pertemuannya menyajikan banyak pemikiran untuk saling dibagikan dalam membenahi administrasi kota-kota. Dan berkala Locale Techniek sebagai organ teknisnya merekam dan menerbitkan banyak paper atau artikel dalam forum-forum yang diselenggarakan, yang berkaitan dengan penataan kota di segi administrasi, tata kota, arsitektur, hukum, maupun ekonomi dan pembiayaannya.

Terbit di Semarang, berkala Locale Techniek dikendalikan oleh arsitek Thomas Karsten dan stafnya. Berkala ini kemudian terbit dalam dua bahasa: Belanda dan Melayu, untuk memperluas lingkar pembacanya. Demikian pula berkala ini berjasa dalam memunculkan nama-nama stafnya -seperti Moch. Enoch, Soesilo, Abikoesno- sebagai penerjemah dan penulis artikel. Ketiganya kelak akan menjadi pelopor arsitek Indonesia setelah kemerdekaan.

Di luar keempat berkala itu, para arsitek yang bekerja di Hindia-Belanda juga mengenal dan membaca buku, berkala dan koran terbitan Belanda yang beredar di Hindia-Belanda. Berita mengenai pembangunan karya arsitektur 
modern di luar negeri bisa diikuti lewat berbagai berkala impor ini.

Perkembangan wacana Identitas Arsitektur yang muncul dalam keempat berkala di atas, tampil sebagai artikel, laporan perjalanan maupun laporan proyek konstruksi. Berangsur-angsur berkala itu dari sekadar melaporkan proyek pembangunan lokal, kemudian lebih maju lagi menerbitkan artikel yang mengapresiasi produk budaya lokal, baik yang teraga maupun tidak [tangible-intangible], hingga perlunya melakukan modernisasi arsitektur dan kebudayaan lokal agar dunia bisa menghargai usaha Belanda dalam membimbing penduduk tanah jajahan mencapai taraf kemodernan seperti mereka.

Peran sebagai pembimbing ini merupakan peran yang umum dimainkan oleh negaranegara kolonial seperti Belanda, Inggris dan Prancis dalam berhubungan dengan penduduk tanah jajahan.

KIVI baru dalam edisi tahun kedua (1899:12-59) menerbitkan artikel mengenai pembangunan penyediaan air bersih di Singomerto, Banyumas, Jawa Tengah. Adapun IBT, sudah menampilkan ulasan tentang pembangunan irigasi lembah Benegawan Solo pada edisi ke-6 bulan Desember tahun pertama 1898. Laporan KIVI itu disertai dengan peta dan gambar-gambar teknik, suatu kecenderungan publikasi teknis sejaman yang sedang giat menjalankan penataan infrastruktur irigasi, jalan raya dan pelabuhan yang amat dibutuhkan untuk kepentingan ekonomi dan pertahanan pemerintah kolonial. Distribusi arsitek dan teknisi bangunan, menurut alamat keanggotaan KIVI maupun VvBNI yang disertakan pada edisi perdana, memang kebanyakan berada di daerah aliran Sungai Serayu, Bengawan Solo dan Sungai Brantas Jawa Timur.

Fakta lapangan yang dilaporkan kedua berkala itu mendapatkan legalitasnya 5 tahun kemudian (1903), ketika Politik Etis dengan semboyannya: perbaikan irigasi, pemerataan persebaran penduduk, dan peningkatan pendidian pribumi secara resmi dimaklumkan berdasarkan Pidato Kerajaan Belanda 1901.

Politik Etis itu muncul karena suasana di Hindia-Belanda di akhir abad XIX sudah mulai menggelisahkan. Salah satu pemicunya adalah tulisan Pieter Broosooft di koran Semarangsche Courant 1877 tentang beratnya penderitaan rakyat Jawa karena eksploitasi colonial (Ethische politiek, 2016). Disambung oleh perdebatan di parlemen sehingga diperlukan kebijakan baru untuk tetap mempertahankan Hindia Belanda sebagai tanah jajahan.

Teknisi bangunan sebagai ujung tombak pembangunan infrastruktur daerah jajahan mendapatkan peran penting namun kualitasnya kurang memenuhi kebutuhan sehingga VvBNI secara rutin menyelenggarakan ujian sertifikasi dan berkala IBT menerbitkan soal-soal bagi calon teknisi yang ingin mengikuti tes sertifikasi itu.

IBT pada edisi ke-6 itu juga sudah menampilkan iklan tentang bahan baru untuk bangunan, terutama semen portland, suatu bahan import yang amat diandalkan bagi pembangunan dam, pelabuhan dan pintu-pintu irigasi. Sosialisasi bahan semen dan artikel tentang beton bertulang (gewapend beton) gencar di kedua berkala, menyusul pembangunan pabrik semen pertama pada 1910 di Indarung, Padang.

Iklan adalah kekuatan finansial pendukung penerbitan berkala IBT, selain juga sumber informasi bahan-bahan baru.

Sedangkan informasi tentang bangunan baru, IBT melaporkan perkembangan arsitektur di Belanda namun tidak disertai gambar. Foto pertama justru dipakai untuk melaporkan pembangunan limpasan air dam Simping, Jawa Barat. Pada edisi-edisi berikut, IBT memainkan peran lebih aktif dalam mengenalkan hal-hal baru dari luar dan menyajikan laporan lapangan dengan memakai teknik foto yang tergolong inovasi baru pada waktunya.

Dua tahun penerbitan IBT, dalam edisi Januari 1900: h.9-12 diawali artikel bersambung mengenai Sejarah Arsitektur, yakni uraian mengenai jenis-jenis kolom Yunani dengan disertai gambar tampak dan potongan. Dan baru pada edisi November 1900 muncul laporan singkat tentang biaya yang diperlukan untuk renovasi Boroboedoer.

IBT memberi perhatian pada pelatihan para teknisi dan tukang. Tulisan awal di edisi April 1906 hanya berupa kutipan dari koran De Locomotief mengenai perlunya segera didirikan sekolah ketukangan di Malang. Sejak tahun 1910 semakin banyak tulisan yang berisi desakan publik mengenai perlunya didirikan sekolah keteknikan. Juga dalam tahun ini pula candi Mendut dan Borobudur ditulis secara apresiatif dan arsitektural.

Demikianlah, IBT semakin memberi perhatian pada masalah lokal dan mendorong 
keinginan untuk melakukan modernisasi pada arsitektur lokal dan tirasnya semakin naik, terlebih dengan pecahnya Perang Dunia I pada tahun 1914. Meski pun Belanda yang tidak ikut terlibat perang tapi ikut terkena dampaknya, yakni terganggunya hubungan Belanda dengan tanah jajahan sehingga yang berada di tanah jajahan muncul gairah untuk mengambil jarak serta ada usaha merumuskan identitas diri.

Berkala NION yang adalah majalah terbitan biro arsitek Cuypers, sejak semula sudah menaruh perhatian pada kebudayaan pribumi. Pada tahun pertama penerbitannya, sudah muncul artikel tentang Kantor Pusat Perusahaan Kereta Api SCS di Tegal. Kantor ini dirancang oleh Henri Maclaine Pont untuk menghadirkan konsep "bouwen in de tropen' atau bangunan Barat di tanah tropik. Yang ditulis di sini, selain mengenai prinsip-prinsip pencahayaan dan ventilasi alami pada bangunan, juga pelestarian ketukangan lokal yang harus dipandu oleh akal budi Barat yang telah terceahkan.

Sikap yang lebih jelas nampak pada rancangan Pameran Kolonial di Semarang 1914. Ini merupakan usaha untuk memperlihatkan perpaduan antara Barat dan Timur. Uraian ini diterbitkan kemudian di NION 1919, h. 47-64. Di situ sudah ada kesadaran untuk merumuskan identitas arsitektural campuran antara kedua kebudayaan, yang dikenal sebagai asimilasi antara Barat-Timur.

Di IBT, tulisan perdana tentang arsitektur modern baru muncul oleh arsitek Semarang Abikoesno pada edisi Desember 1921, h.477480 dengan judul Iets over Moderne Architectuur. Artikel ini menggunakan rujukan tulisan HP. Berlage dan RLA. Schoemaker untuk memperjuangkan style (langgam) yang berkarakter, tidak hanya mengambil arsitektur modern dari Barat yang tidak cocok dengan udara panas terik dan hujan deras kawasan tropik. "Sebuah bangunan dengan karakter akan lebih bertahan, sedangkan yang hanya mengikuti mode, sebagus apa pun modisnya, akan mudah ketinggalan jaman" (Tjokrosujoso, 1921).

Perjuangan langgam yang berkarakter lokal ini diwujudkan oleh Maclaine Pont melalui rancangan kampus ITB di Bandung. Ia menolak membuat siteplan dengan gubahan massa tunggal, tapi lebih memilih massa jamak untuk mengikuti penataan bangunan-bangunan di kedua kraton Jawa Surakarta dan Yogyakarta. Berawal dari keyakinannya bahwa tukang kayu
Jawa itu berpotensi tapi kurang percaya diri, maka Pont perlu membangunkan percaya diri mereka itu melalui modernisasi arsitektur Jawa. Meski pun atap bangunan barak di kampus ITB itu menggunakan atap Minangkabau, tapi yang ia hendak capai adalah kebangunan tradisi membangun Jawa.

Usaha ini diketahui oleh arsitek Belanda Berlage dan membawanya pada ceramahnya di Lembaga Kerajaan untuk para Insinyur, dan kemudian dituliskan di De Ingenieur dengan judul "De Europeesche Bouwkunst op Java"( erlage, 1924).

Berlage menamai langgam yang sedang diusahakan Maclaine Pont, Thomas Karsten dan Gerber sebagai Indo-Europeesche Stijl, sesuai dengan paham dia yang mengikuti Gottfried Semper mengenai langgam yaitu "...ekspresi arsitektural yang secara jujur memperlihatkan bagaimana ia terbangun oleh kondisi-kondisi semasanya" (Berlage, 1996).

Identitas arsitektural dalam hal ini dianggap bisa dikonstruksikan bila kita mampu mengenali karakteristik semangat jamannya.

Locale Techniek terbit ketika persoalan kampung di perkotaan sudah menjadi masalah, yakni kebersihan dan kesehatan. Berkala ini terbit ketika krisis ekonomi sudah selesai dan gerakan-gerakan nasionalisme sudah makin menguat. Sebagaimana maksud diterbitkannya berkala ini untuk sarana komunikasi dan meratakan pengertian mengenai penataan kawasan perkotaan, maka karakter berkala ini sudah ditentukan. Belum ada penelitian mendalam mengenai peran penting berkala ini pada tata kota, sementara banyak sekali tulisan Thomas Karsten diterbitkan dalam berkala ini. Salah satu yang terkenal adalah Indiese Stedebouw (Perencanaan Kota secara Hindia), suatu paparan mengenai prinsip-prinsip dalam perencanaan kota di Hindia Belanda.

\section{KESIMPULAN}

Studi sekilas memberi gambaran bahwa wacana identitas dalam arsitektur itu muncul dan berkembang secara berangsur-angsur, seiring dengan makin banyaknya persoalan lokal yang harus diselesaikan oleh para teknisi bangunan.

Jurnal resmi ikatan Teknisi Bangunan IBT dan KIVI semakin meninggalkan isinya yang terlampau teknis, menuju ke topik-topik yang lebih estetik dan mempertimbangkan 
sejarah serta tradisi membangun lokal. Demikian pula partisipasi penulis dan ahli bangunan lokal semakin diberi tempat. Kecenderungan melokal itu didorong oleh faktor-faktor material seperti perang, meningkatnya arus perdagangan, situasi politis yang mendukung itu.

Berkala-berkala itu -dengan mengesampingkan KIVI yang sudah tutupmencapai puncak fungsinya pada dekade 20 -an. Arus politik kolonial masa itu disebut sebagai Arus Etik (Etische Koers) atau Etische Politics atau Politik Etik, yakni suatu kebijakan yang mengganti politik represi dengan politik yang lebih memberdayakan pribumi lewat pendidikan dan ketrampilan.

Dengan demikian wacana identitas arsitektural adalah akibat saja dari kekuatankekuatan ideologis material yang menghadirkannya.

Publikasi tercetak yang merekam dinamika percakapan atau diskusi mengenai hal ini memperlihatkan bahwa mula-mula memang ada kebutuhan alami untuk menyesuaikan bangunan modern dengan iklim tropik lembab. Usaha pada teknisi bangunan dapat diikuti dengan jelas dari berkala KIVI maupun IBT, baik untuk infrastruktur maupun bangunan.

Bangunan yang berkarakter baru muncul dalam diskusi di media ketika kondisi berikut ini terjadi: Perang Dunia I, Politik etis, mekarnya kehidupan urban, dan krisis ekonomi dunia.

Kajian terhadap perkembangan berkala ini juga memberi informasi mengenai beragamnya pemahaman tentang moderniasi arsitektur.

Secara umum, keempat berkala yang terbit di Hindia Belanda ini menjadi saksi sejaman mengenai proses terbentuknya wacana identitas arsitektur. Ada tekanan ekonomi yang membuat para arsitek harus lebih mengarahkan perhatian kepada situasi lokal. Mengikuti saran Berlage dan Semper, arsitek masa kini janganlah mengejar konstruksi identitas itu. Ia akan datang sendiri sebagai cermin kejujuran arsitektur dalam menanggapi situasi ideologis material sejamannya.

\section{Daftar Pustaka}

A. Tjokrosujoso (1921) "Iets over Moderne Architectuur," Indisch Bouwkundig Tijdschr., vol. 24, no. 24, pp. 477-480.

A. B. A. Adam, A. Loebis, M. Joebhaar, and E. Endarmoko (2003), Sejarah awal pers dan kebangkitan kesadaran keindonesiaan, 1855-1913. Hasta Mitra.

B. Colomina, Privacy and publicity: Modern Architecture as Mass Media. MIT press Cambridge, MA, 1994.

O. Anderson (2006) Imagined Communities: Reflections on the origin and spread of Nationalism. Verso Books.

D.G. Stibbe (1921) Encyclopaedie van Nederladsch-Indie: 2de druk, vol. 5de deel. 's Gravenhage: Martinus Nijhoff.

“Ethische politiek,” Wikipedia. 27-Sep-2016.

H. P. Berlage (1996) Hendrik Petrus Berlage: thoughts on style, 1886-1909. Santa Monica, CA: Getty Publications.

H. P. Berlage (1924) "De Europeesche Bouwkunst op Java," Ing., vol. 22, no. 39.

H. M. Pont (1916) "Het Nieuwe Hoofdbureau der Semarang-Cheribon Stoomtrammatschappij te Tegal," Ned.Indie Oud En Nieuw, vol. 1, no. 1, pp. 89-98.

K. Rattenbury (2002) This is not architecture: media constructions. Psychology Press.

Mahatmanto (2004) "Publikasi Pemikiran Henri Mclaine Pont di DJAWA," DIMENSI J. Archit. Built Environ., vol. 30, no. 2, pp. 110-121.

Mahatmanto (2014) "Media dan Awal Arsitektur Modern di Indonesia," in Seminar Nasional Sainstek ke-2, pp. 339-344. 
Mahatmanto (2015) "Role of the Journal of Building Engineers in Dutch East India In Discussing the Emergence of Indonesian Modern Architecture," $J$. ASIAN Archit. Build. Eng., vol. 14, no. 3, pp. 529-532.

P. Collier and Ann L. Ardis (2008), Transatlantic Print Culture, 1880-1940: Emerging Media, Emerging Modernisms. New York: Palgrave Macmillan.

R. Scholes and C. Wulfman (2010), Modernism in the Magazines: An Introduction. Yale University Press. 